\title{
Developing nurse leaders across the Americas: evaluation of an online nursing leadership course
}

\author{
Johis Ortega, ${ }^{1}$ Mary Hooshmand, ${ }^{1}$ Cynthia Foronda, ${ }^{2}$ Maria Padron, ${ }^{2}$ \\ Desiree Simon, ${ }^{1}$ Michelle Waters, ${ }^{1}$ Silvia Cassiani, ${ }^{3}$ and Nilda Peragallo Montano ${ }^{4}$
}

Suggested citation Ortega J, Hooshmand M, Foronda C, Padron M, Simon D, Waters M, et al. Developing nurse leaders across the Americas: evaluation of an online nursing leadership course. Rev Panam Salud Publica. 2018;42:e152. https://doi.org/10.26633/RPSP.2018.152

\begin{abstract}
Development of leadership capacities in the nursing workforce is essential to achieving universal health in the Region of the Americas. This evaluation considered the effectiveness of an online leadership course offered in English and Spanish to nurses throughout Latin America and the Caribbean. The online course was an asynchronous eight-module leadership nursing course created and offered by the Pan American Health Organization (PAHO) Virtual Campus. A retrospective, descriptive design was used to evaluate learner performance data from the modules. Learner performance on the course was analyzed. Electronic surveys were distributed to individuals who withdrew prior to course completion to obtain information regarding the reason for withdrawal.

In all, 289 individuals from 41 countries participated in the online course. Learner performance demonstrated improvement from pre- to post-test. The most frequent reason for not completing the course was being too busy with other obligations. The Spanish-language course version received more enrollment applications than any other course in the virtual campus' 12-year history. The evaluation concluded that continuing education that develops nursing leadership is desired across Latin America and the Caribbean. Online education through the PAHO Virtual Campus may be a low-cost yet powerful means of disseminating knowledge to the nursing workforce throughout the Americas.
\end{abstract}

Keywords Education, nursing, continuing; education, distance; health human resource training; Americas.

\footnotetext{
University of Miami School of Nursing and Health Studies, Coral Gables, Florida, United States of America. Send correspondence to Johis Ortega, j.ortega10@miami.edu

2 Pan American Health Organization (PAHO) / World Health Organization (WHO) Collaborating Center, University of Miami School of Nursing and Health Studies, Coral Gables, Florida, United States.

3 Health Systems and Services, PAHO/WHO, Washington, D.C., United States.

4 University of North Carolina School of Nursing, Chapel Hill, North Carolina, United States.
}

Development of leadership capacities in the nursing workforce is essential to achieving universal health in the Region of the Americas. According to Zug and colleagues (1), competent and motivated nursing professionals can efficiently deliver health care to Latin American and Caribbean populations, supporting the initiatives of universal health worldwide. Nurse leaders are influential in shaping practice, health, education, and social policy (2).

During undergraduate nursing studies, leadership as a concept is often underemphasized in favor of developing necessary foundational skills. After $1-2$ years of practice, educational opportunities for emerging nurse leaders in the 
Americas are limited and frequently unavailable in their home countries. In fact, one cross-sectional study of 246 Latin American and Caribbean nursing schools found that only $31.3 \%$ of faculty held doctorate degrees; if Brazil is excluded, this proportion drops to $8.3 \%$ (3).

Recognizing the importance of preparing nurse leaders in the Americas, the University of Miami School of Nursing and Health Studies (Coral Gables, Florida, United States; SONHS), a designated $\mathrm{PAHO} / \mathrm{WHO}$ Collaborating Centre, collaborated with PAHO to develop an online nursing leadership course for the Caribbean and Latin America. After completion of the course by three cohorts consisting of individuals from 41 countries, an evaluation of its usefulness was conducted. This Special Report summarizes the methods and results of that evaluation.

\section{EVIDENCE OF THE NEED FOR NURSE LEADERS}

The landmark Future of Nursing Report (4) by the Institute of Medicine (Washington, D.C., United States; IOM) points to the need for nursing leadership at all levels and in all settings. Inherent in this report is a call to further develop nurse leaders, from the bedside to the boardroom. The IOM Committee on the Work Environment for Nurses and Patient Safety also determined that the role of transformational nursing leadership is crucial in achieving the modifications needed to improve patient safety in health care delivery environments (4). According to Andrews and colleagues (5), nursing staff's perceptions of leadership styles affected their satisfaction with their supervisors and the promotion of nursing excellence. Bish and colleagues' systematic review (6) found that nurse leaders functioning in rural health care environments are equally in need of leadership development resources as their urban counterparts. Finally, at the Global Advisory Panel on the Future of Nursing, convened in July 2015 by Sigma Theta Tau International Honor Society of Nursing in San Juan, Puerto Rico, a select group of visionary nurse leaders from Latin America prioritized nursing leadership as one of four vital issues integral to addressing the health challenges of Latin America (7).

In spite of the demonstrated need for empowering nurse leaders on a global scale, research about best practices in teaching leadership is scant. Buckner and colleagues (8) identified nurse leaders from six nations, including Colombia, who participated in a year-long activity on global-level nursing leadership development. This experience found a lack of mentoring in settings where nurses can impact practice, teaching, and health care policy. The authors recommended that international nursing organizations (e.g., the International Council of Nurses and Sigma Theta Tau International) continue to create infrastructures to enhance global leadership development (8).

Dyess and colleagues' (9) qualitative study using focus groups of three nursing cohorts in the United States examined and categorized emerging nurses' perspectives on leadership and perceived barriers to practice. The three major categories that emerged were (a) "idealistic expectations of leaders;" (b) "leading in a challenging practice environment;" and (c) "cautious, but optimistic outlook about their own leadership and future" (9). Nurses expressed the desire to pursue nursing leadership education despite their hesitancy and concern over practicing in a challenging environment.

A descriptive study targeting a participant pool more closely resembling the demographics of this report's participants was conducted by Villarruel and Peragallo (10). They surveyed barriers and facilitators to the development of 23 Hispanic nurse leaders and found that the definition of a good leader was similar for Hispanic nurses as it was for other ethnic and racial groups. Race and ethnicity were not determining factors in who makes a good leader-rather the individual's ability to lead mattered most (10). Most of the survey participants reported that their nursing leadership education was obtained formally, either via an advanced degree, certified leadership courses, or workshops (10).

The importance of nursing leadership and the growing need for resources to promote it in the Americas were the driving forces behind SONHS and PAHO's partnership to develop an online course aimed at producing nurse leaders in Latin America and Caribbean.

\section{MATERIALS AND METHODS}

\section{Course description}

The course content and format were created and designed by SONHS, the
PAHO/WHO Collaborating Centre at the University of Miami, and PAHO. The course objectives (Box 1) and topics for the modules were determined following consultation between SONHS faculty and the Regional Advisor at PAHO/ WHO headquarters in Washington, D.C., with input from two other PAHO Regional Collaborating Centers: one based in Latin America (Mexico) and the other in the English-speaking Caribbean (Jamaica). An asynchronous, online leadership course, "Nursing Leadership: Empowering Nurses in Latin America and the Caribbean," was developed consisting of a pre-course demographic survey; a diagnostic pre-test; eight modules, including eight within-module exams; a diagnostic post-test; and a course evaluation module. The eight module topics and within-module sub-topics (Box 2) were agreed upon as follows: 1. Evolution of management and leadership theories applied to nursing; 2. Ethics and the role of the nurse as advocate; 3. Leadership of the future; 4. Workforce; 5. Quality improvement and culture of safety; 6 . Evidence-based research; 7. Intra- and interpersonal collaboration: full partners; and, 8. Financial management and cost analysis. Two identical course versions were created, one in English and the other in Spanish. The Spanish version was later revised. The course design enabled capturing of the participants' demographics and knowledge gains, as well as course completion rates. An additional survey was developed to obtain reasons for attrition. Participants were expected to complete the course in 3 months.

SONHS staff collaborated with PAHO staff to install and offer the course on the PAHO Virtual Campus of Public Health (VCPH). VCPH is managed in Drupal ${ }^{\mathrm{TM}}$ (Drupal Assoc., Portland, Oregon, United States), and the "classrooms" in Moodle $^{\mathrm{TM}}$ (Martin Dougiamas, Moodle, Perth, Australia), both of which are opensource, customizable, interface-friendly software programs.

\section{Course participants and cohorts}

For the English and first Spanish versions, the PAHO Regional Advisor on Nursing and Allied Health Personnel invited nurses in leadership positions (e.g., head nurse, nursing supervisor, or unit manager) in Latin America and the Caribbean to participate. At a minimum, candidates had a Bachelor of Science 


\section{BOX 1. General and specific learning objectives of an online course to develop nursing leadership in Latin America and the Caribbean}

General objectives

A self-paced course designed to empower Latin American and Caribbean nursing leadership by providing participants with an overview of the nursing leadership and management principles of the United States, with the intention that these be adapted to the local context.

Learning objectives

Upon finishing the course, participants should be able to:

1. Identify nursing knowledge from the natural and behavioral sciences, arts, humanities, and nursing science as a basis for culturally competent nursing practice.

2. Analyze concepts of organizational theory, systems leadership, workforce development, and quality improvement, utilizing evidence-based research in clinical decision making to promote safe quality care to culturally diverse persons, families, and communities.

3. Discuss the impact of current and emerging information management and patient care technology in nursing practice

4. Discuss the impact of socio-political-economic influences on the practice of professional nursing at varying governmental levels, including the role of the nurse as advocate, and emphasizing the importance of inter-professional communication in improving patient health outcomes.

5. Apply ethical standards and professional values to nursing practice

Source: Prepared by the authors from study data.

degree from a university. A committee made up of the PAHO Regional Advisor on Nursing and Allied Health Personnel and the two principal course authors made the final selections. Enrollment in the program was coordinated by the VCPH. Enrollment goals for the English and Spanish versions were 50 and 100 participants, respectively, but due to the number of highly-qualified applicants, the selection committee slightly increased the size of each cohort. The committee also took diversity into consideration, including participants from as many countries as possible. The course was only available to the study participants.

Following excellent feedback from previous participants and through word-of-mouth, the Ministry of Public Health of Uruguay contacted PAHO to request that the course be offered to its nursing leaders. Enrollment for the Uruguay course was co-managed by the PAHO Country Office and the Ministry of Public Health. They initially planned on enrolling 100 participants, but due to the high demand, the number was raised to 120 . The Ministry of Public Health added tutors to the course to make it more interactive and to offer a more direct way to ask questions.

In all, the online course was offered to three separate cohorts: Cohort 1 consisted of participants from 24 English-speaking Caribbean countries taking the English version of the course from March - June 2015; Cohort 2, participants from 19 Spanish-speaking Latin American and Caribbean countries taking the Spanish version in May - August 2015; and Cohort
3, participants from Uruguay taking a revised version of the Spanish course from July - October 2016 (Table 1).

\section{Course evaluation methods}

A retrospective, descriptive design was used to evaluate existing course data. Preand post-test data were evaluated for all participants. In addition, all modules' mean performance scores were examined separately and collectively. To receive a certificate of completion, participants had to achieve a score of $80 \%$ on the post-test taken upon completion of the modules and the course. Only data from those who completed all modules were included. All data were de-identified and aggregated with descriptive statistics calculated. The data were analyzed and presented separately by cohort.

To evaluate course attrition, a brief, anonymous survey was emailed to individuals who did not complete the course. They were asked to select multiple responses from seven possible reasons for not having completed the course; thus, the total percentages of selected responses could exceed 100\%. Responses were tabulated and presented by percentage of frequency.

In addition to evaluating student performance resulting from the training, their perception of the course was also assessed. Questions evaluated a variety of course characteristics, including its effectiveness, the alignment of course content with learning objectives, the relevance of the content, and the application of course content to nursing practice. Evaluating the data collected from the course's first three offerings, its developers produced a report of its outcomes. These results will be used to positively inform future iterations and efforts.

Ethics. The evaluation protocol was submitted for ethical approval to the Human Subjects Research Office of the University of Miami (Coral Gables, Florida, United States) and determined to be "not human subjects research."

\section{RESULTS}

\section{Sample}

Cohort 1 comprised 58 individuals (55 female and 3 male) located in 23 primarily English-speaking Caribbean countries (Table 2). Most of these individuals $(91 \%)$ indicated working in the public as opposed to the private $(3.5 \%)$ or not for profit $(2 \%)$ sector. Of the 58 participants, $7 \%$ reported having some college education; 38\%, a bachelor's degree; $43 \%$, a master's degree; and $12 \%$, a doctoral degree. Most participants (62\%) were employed in nursing administration, with $33 \%$ working in education and the remaining $5 \%$ at the bedside. Nearly $80 \%$ of participants reported having completed their nursing degree at least 10 years prior. In terms of age, $2 \%$ of participants were less than 20 years of age; $2 \%$ were 20 - 25 years; $10 \%$ were 26 40 years; $72 \%$ were 41 - 55 years; and $14 \%$ were 56 or older. Of the 58 enrolled participants, 48 completed the course, making the completion rate $83 \%$. 


\section{BOX 2. Modules and content of an online course to develop nursing leadership in Latin America and the Caribbean}

Module 1: Evolution of management and leadership theories applied to nursing

Module 2: Ethics and the role of nurse as advocate

Module 3: Leadership of the future

Module 4: Workforce

Module 5: Quality improvement and culture of safety

Module 6: Evidence-based research

Module 7: intra- and interprofessional collaboration - full partners

Module 8: Financial management and cost analysis
- History of management styles and leadership theories

- Application of these theories to patient care settings

- Ethics/ethical dilemmas

- Leadership roles

- Principles of ethical reasoning

- Ethics and the nursing process

- Essentials of professionalism in the workplace

- Leadership competencies

- Technology

- Leading in a rapid-change health care environment

- The role of the nurse in health policy and health systems

- Staffing and safe staffing

- Generational differences in the workforce today

- Recruitment/retention

- Human resources leadership and management as applied to the nursing workforce

- Performance appraisals: evaluating the nursing professional (in-service training)

- Hallmarks of an effective Quality Improvement (QI) program

- QI (Joint Commission and HRSA) initiatives

- Benchmarking

- Standards and measures

- Audits/performance improvement

- Safety measures taken by nurses

- Involving patients in safety initiatives

- Shared governance in the hospital

- Foundation for research and knowledge development in nursing

- Importance of and barriers to Evidence-Based Practice (EBP) in nursing

- Definition and process of EBP

- Retrieving and applying evidence

- EBP models in nursing

- Basics of team building and coaching

- Definition and operationalization of critical team concepts

- High-performing teams

- Communication/principles of communication

- Negotiation and conflict management among the team

- Budgets

- Financials/cost analysis

- Triple aim: cost, quality, and access to care

Source: Prepared by the authors from study data.

Cohort 2 comprised 111 participants (98 female and 13 male) located in 20 primarily Spanish-speaking countries of Latin America or the Caribbean. Most of these individuals indicated working in the public (83\%) as opposed to private $(12.5 \%)$ or not for profit $(1 \%)$ sector. Four individuals $(3.5 \%)$ indicated having some college education: $39 \%$ held a bachelor's degree; 53\%, a master's degree; and $4.5 \%$, a doctoral degree. Most participants (59\%) were employed in nursing administration, with $37 \%$ working in education and $4 \%$ at the bedside. Most participants (83\%) reported having completed their nursing degree at least 10 years prior. None of the participants were less than 20 years of age; $1 \%$ were 20 - 25 years; $29 \%$ were $26-40$ years; $56 \%$ were 41 55 years; and $14 \%$ were 56 years or older. Of the 110 enrolled participants, 83 completed the course, making the completion rate $76 \%$.

Cohort 3 comprised 120 individuals (111 female and 9 male) located in the primarily Spanish-speaking country of Uruguay. Most of these participants indicated working in public $(51.5 \%)$ as opposed to the private $(47.5 \%)$ or not for profit $(1 \%)$ sector. Five of these individuals $(4.5 \%)$ indicated having some college education; $89 \%$, a bachelor's degree; $6.5 \%$, a master's degree; and none had a doctoral degree. Most participants $(71.6 \%)$ were employed in nursing administration, with $16.6 \%$ working in education and $11.6 \%$ percent at the bedside. More than one-half $(63 \%)$ reported having completed their nursing degree at least 10 years prior. None of the participants were less than 20 years of age; $0.8 \%$ were $20-25$ years; $50.8 \%$ were 26 - 40 years; $37.5 \%$ were 41 - 55 years; and $10.9 \%$ were 56 years or older. Of 120 enrolled participants, 89 completed the course, making the completion rate $74 \%$. 


\section{Learner performance}

Cohort 1: English-speaking countries in the Americas. Of a possible $100 \%$, the average score on the pre-test was $65 \%$; on the post-test, $87 \%$. The mean total performance score on the modules was $95.4 \%$. Participants scored highest on Module 4: Workforce $(98.9 \%)$ and lowest on Module 5: Quality improvement and culture of safety assessment (91.5\%). Overall course satisfaction was overwhelmingly positive (Table 2).

As for those who did not complete the course, $54 \%$ chose the reason "too busy with other obligations;" 37\%, "other reasons;" 14\%, "technical issues;" $6 \%$, "course content was not relevant to nursing studies or nursing practice;" and 3\%, "the course was too long."

TABLE 1. Course participants, by cohort and country of residence, in an online course to develop nursing leadership in Latin America and the Caribbean

\begin{tabular}{|c|c|c|c|c|c|}
\hline \multicolumn{2}{|c|}{ Cohort 1: English } & \multicolumn{2}{|c|}{ Cohort 2: Spanish } & \multicolumn{2}{|c|}{ Cohort 3: Uruguay } \\
\hline Country & $\begin{array}{l}\text { Number of } \\
\text { participants }\end{array}$ & Country & $\begin{array}{c}\text { Number of } \\
\text { participants }\end{array}$ & Country & $\begin{array}{l}\text { Number of } \\
\text { participants }\end{array}$ \\
\hline Algeria & 1 & Algeria & 1 & Uruguay & 120 \\
\hline Anguilla & 5 & Argentina & 4 & & \\
\hline Antigua/Barbuda & 1 & Bolivia & 7 & & \\
\hline Azerbaijan & 4 & Brazil & 3 & & \\
\hline Bahamas & 8 & Chile & 6 & & \\
\hline Barbados & 1 & Costa Rica & 6 & & \\
\hline Belgium & 4 & Columbia & 6 & & \\
\hline Belize & 4 & Cuba & 9 & & \\
\hline Botswana & 2 & Dominican & 8 & & \\
\hline Brazil & 1 & Ecuador & 5 & & \\
\hline British V.I. & 1 & El Salvador & 7 & & \\
\hline Cayman Islands & 1 & Guatemala & 5 & & \\
\hline Germany & 4 & Honduras & 5 & & \\
\hline Grenada & 4 & Mexico & 9 & & \\
\hline Guatemala & 2 & Nicaragua & 4 & & \\
\hline Guinea & 1 & Panama & 4 & & \\
\hline Ireland & 1 & Paraguay & 3 & & \\
\hline Oman & 1 & Peru & 12 & & \\
\hline Romania & 1 & Uruguay & 4 & & \\
\hline Timor Leste & 3 & Venezuela & 3 & & \\
\hline Trinidad/Tobago & 5 & & & & \\
\hline United Arab Emirates & 1 & & & & \\
\hline United States of America & 1 & & & & \\
\hline
\end{tabular}

Source: Prepared by the authors from study data.
Cohort 2: Spanish-speaking countries in the Americas. The average score on the pre-test was $57.5 \%$; on the post-test, $83.9 \%$. The mean total performance score on the modules was $90.3 \%$. Participants scored highest on Module 4: Workforce $(95.7 \%)$ and lowest on Module 3: Leadership of the future $(82.9 \%)$.

Overall course satisfaction was overwhelmingly positive (Table 2). As for those who did not complete the course, $43 \%$ chose the reason "too busy with other obligations;" 29\%, "the course was too long," $14 \%$, the "course content was too dull;" and 14\%, "other reasons."

Cohort 3: Participants from Uruguay. The average score on the pre-test was $53.4 \%$; on the post-test, $78.4 \%$. The mean total performance score on the modules was $89.6 \%$. Participants scored highest on Module 4: Workforce (96\%) and lowest on Module 5: Leadership of the future $(82.7 \%)$. Overall course satisfaction was overwhelmingly positive (Table 2). A total of $31(26 \%)$ participants did not complete the course. Data about the reasons of not completing the course is not available for the Uruguay cohort.

In summary, the overwhelming majority of participants in all three cohorts agreed or strongly agreed with all statements indicating that the training was useful.

\section{DISCUSSION}

An evaluation of the pre- and postcourse diagnostic tests and post-course satisfaction evaluation data reveals that the course appeared to positively impact learning in the area of nursing leadership

TABLE 2. Participants' ratings of an online course on nursing leadership for Latin America and the Caribbean $(n=224)$

\begin{tabular}{|c|c|c|c|c|c|c|}
\hline \multirow[b]{2}{*}{ Statement } & \multicolumn{6}{|c|}{ Rating } \\
\hline & $\begin{array}{l}5 \text { Strongly } \\
\text { agree } \%\end{array}$ & $\begin{array}{c}4 \\
\text { Agree \% }\end{array}$ & $\begin{array}{c}3 \\
\text { Neutral \% }\end{array}$ & $\begin{array}{c}2 \\
\text { Disagree \% }\end{array}$ & $\begin{array}{l}1 \text { Strongly } \\
\text { disagree \% }\end{array}$ & $\begin{array}{c}\text { No } \\
\text { answer \% }\end{array}$ \\
\hline I would recommend this course to a colleague. & 83 & 15 & 1 & 0 & 0 & 0 \\
\hline The course material is presented effectively. & 67 & 28 & 4 & 0 & 0 & 0 \\
\hline The case studies and thinking questions stimulate interest in the material. & 63 & 33 & 5 & 0 & 0 & 0 \\
\hline The material in the modules reflects the learning objectives of the course. & 71 & 27 & 2 & 0 & 0 & 0 \\
\hline This course has challenged me to think. & 73 & 25 & 1 & 0 & 0 & 0 \\
\hline The quizzes accurately assessed what I have learned in this course. & 59 & 35 & 5 & 1 & 0 & 0 \\
\hline The difficulty of the course was appropriate. & 39 & 48 & 9 & 1 & 0 & 3 \\
\hline The course material was relevant to my nursing practice. & 70 & 28 & 2 & 0 & 0 & 0 \\
\hline The material was culturally appropriate to me. & 62 & 36 & 2 & 1 & 0 & 0 \\
\hline I learned something new. & 80 & 19 & 1 & 0 & 0 & 0 \\
\hline I am confident that I can apply what I have learned to my nursing practice. & 76 & 22 & 1 & 0 & 0 & 0 \\
\hline
\end{tabular}

Source: Prepared by the authors from study data. 
and was perceived by participants as relevant to their professional development. There was an increase in knowledge of nursing leadership principles from pre- to post-tests among all cohorts. Completion rates were high, ranging from $74 \%-83 \%$. All three cohorts performed well on the eight within-module final exams. The approximately $90 \%$ mean score on the final exam demonstrates a solid understanding of the course content.

SONHS was notified that this was the first nursing leadership course offered by $\mathrm{VCPH}$ since the portal was launched in 2003. Moreover, the first Spanishlanguage version of the course in 2015 had more applications than any other course in the portal's 12-year history, signifying a strong interest and need for nursing leadership education in the Americas.

All three cohorts performed best on Module 4: Workforce. Interestingly, two of the three cohorts scored lowest on Module 3: Leadership of the future, indicating a gap that may potentially be addressed by creating future educational resources for this population.

Furthermore, although the difference is slight, Cohorts 2 and 3 performed lower on the Module 3 post-test, demonstrating a lack of mastery on the topic of leadership. The course content was originally developed in English by individuals who resided in and received their nursing education in the United States. It was translated into Spanish by individuals fluent in both languages. This may signify that cultural differences exist in the interpretation of strong leadership. To address this potential cultural bias, SONHS partnered with two other $\mathrm{PAHO} / \mathrm{WHO}$ Collaborating Centers: the University of the West Indies (Mona, Jamaica) and the Colombian Association of Schools and Faculties of Nursing (Bogotá, Colombia). Faculty from these two partners reviewed the course content and recommended revisions that were integrated into the original final course modules, increasing the relevancy of the material to the practice of nursing care, research, and education in Latin America and the Caribbean. Nevertheless, cultural context must be considered. On the other hand, the demographic data indicated that the English-language cohort was more highly educated, a difference that could explain the disparity in performance.
Across all cohorts, the most common reason for not completing the course was being too busy with other obligations. Although not surprising, this data indicates that technical issues experienced by the participants were not insurmountable. Furthermore, the demographic module data revealed that the largest percentage of participants graduated from their nursing programs at least 10 years prior to taking the course. This indicates that the audience for leadership development training consists of seasoned nurses. Some may assume that more experienced nurses may not be comfortable learning through online pedagogy; however, the data from this study suggests otherwise.

The majority of participants were working in the public health sector. As the course was offered on the VCPH, a well-known PAHO resource for public health nurses in the Americas, this was expected. However, it may signify an opportunity to reach out to bedside and private sector nurses with educational offerings on nursing leadership.

\section{Future implications and lessons learned}

Valuable lessons were learned in undertaking this course design and development, implementation, and evaluation. In future iterations, it is imperative that individual data be matched with pre- and posttest scores to allow for calculation of statistically significant changes. For evaluation purposes and since not all individuals completed the pre- and post-tests, completion of the pre-test should be required prior to granting access to the module content. Similarly, requiring completion of the post-test should be required prior to issuing a certificate of completion.

Designing a course for a global audience has some challenges. Given the nature of a diverse audience with differing nursing practices and various hierarchical structures and contexts, we feel it is vital to share evidence-based knowledge to germinate new ideas and practices. Ideally, each leadership course would be tailored to meet the varying cultural contexts and levels of the participants. Additionally, the concepts taught should be based on core leadership principles designed for transformative or systems level change.

The goal of this course, as suggested by the PAHO Regional Office, was to train nurses currently serving in leadership positions, individuals who may have developed some leadership skills in previous training or on the job through years of practice. A shorter, simpler online course with fewer modules covering basic leadership knowledge could be beneficial to new nurses who would like to take leadership positions in the future.

Limitations. This study was limited in several ways. In the interest of protecting personal identity, pre- and post-test data were not individually matched; thus, statistical significance could not be calculated. Due to technical difficulties with the pre-test for Cohort 2, the Spanishlanguage cohort, 2 of the 15 pre-test/ post-test items were excluded in the calculations. The data from Cohorts 1 and 2 consisted of individuals taking the course in various countries, while all of the participants in Cohort 3 were from Uruguay. Data may be interpreted differently if separated out country-by-country. Results from the English-language cohort cannot be generalized to the Caribbean area because some participants from outside the area were enrolled.

\section{Conclusions}

This study reveals that participants in nursing leadership roles across all cohorts benefited from the nursing leadership course. There was a substantial improvement between pre-and post-test scores, and student perceptions of the course were determined to be positive. This study supports the provision of formalized leadership education in both English and Spanish to the PAHO nursing community and throughout the Region of the Americas through online teaching methods.

Further research in the area of nursing leadership is needed. Specifically, knowing more about the perceived barriers to nursing leadership education and working to better understand learning styles and preferred course materials may help improve global education efforts. Comparison of different modalities of teaching to achieve specific learning outcomes and indicators of nursing leadership is the next step. Finally, a longitudinal follow-up would be helpful to assess participants for the performance of nursing leadership roles, accomplishments, and related outcomes. 
Acknowledgements. The authors wish to express special thanks to the Doctor of Nursing Practice students at the University of Miami who led the content development for the eight modules of the online nursing leadership course: Nichole Crenshaw, Shavone Johnson, Joanne Christopher-Hines, Claudia Warren-Taylor, Lainey Kieffer, AnaLisa Chery, Salma Hernandez, and Lorraine Marie Keith. A special thanks also to the

1. Zug KE, Cassiani SHDB, Pulcini J, Garcia AB, Aguirre-Boza F, Park J. Advanced practice nursing in Latin America and the Caribbean: regulation, education, and practice. Rev Lat Am Enfermagem. 2016;24:2807. Available from: doi:10.1590/1518-8345.1615.2807 Accessed 28 June 2017.

2. Ferguson SL. The ICN-Burdett global nursing leadership institute creates outstanding world class nurse executives. Nurse Lead. 2015;13(5):49-51. Available from: doi:10.1016/j.mnl.2015.07.005 Accessed 28 June 2017.

3. De Bortoli Cassiani SHDB, Wilson LL, de Souza Elias Mikael S, Moran-Pena L, Zarate-Grajales RA, McCreary LL, et al. The situation of nursing education in Latin America and the Caribbean towards universal health. Rev Lat Am Enfermagem. 2017;25(2913):1-14. Available from: doi:10.1590/1518-8345.2232.2913 Accessed 28 June 2017.

4. Institute of Medicine. The future of nursing report: leading change, advancing health. Washington, DC: National Academies Press; 2011. Available from:
University of the West Indies School of Nursing, and the Colombian Association of Schools and Faculties of Nursing, $\mathrm{PAHO} / \mathrm{WHO}$ Collaborating Centres that collaborated with us on this project. In addition, this course would not have been possible without the support of the PAHO Virtual Campus of Public Health staff: Rosa Maria Borrell, Edgardo de Gracia, Gabriel Listovsky, and Ana Milena Paredes; and from the University

\section{REFERENCES}

doi: 10.17226/12956 Accessed 28 June 2017.

5. Andrews DR, Richard DC, Robinson P, Celano P, Hallaron J. The influence of staff nurse perception of leadership style on satisfaction with leadership: a crosssectional survey of pediatric nurses. Int J Nurs Stud. 2012;49(9):1103-11. Available from: doi:10.1016/j.ijnurstu.2012.03.007. Accessed 28 June 2017.

6. Bish M, Kenny A, Nay R. A scoping review identifying contemporary issues in rural nursing leadership. J Nurs Scholarsh. 2012;44(4):411-7. Available from: doi:10.1111/j.1547-5069.2012.01471.x Accessed 28 June 2017.

7. Adams J. Key Latin American nurse leaders identify regional issues during Global Advisory Panel on the future of nursing meeting. Proceedings of the Global Advisory Panel on the Future of Nursing (GAPFON), 20-21 July 2015. San Juan: PRW Holdings; 2015. Available from: www.prweb.com/releases / 2015/08/ prweb12879237.htm. Accessed 28 June 2017. of Miami School of Nursing and Health Studies: Khitam Azaiza and Kristiana Yao.

Conflicts of interest. None declared.

Disclaimer. Authors hold sole responsibility for the views expressed in the manuscript, which may not necessarily reflect the opinion or policy of the RPSP/ PAJPH and/or PAHO.
8. Buckner E, Anderson D, Garzon N, Hafsteinsdóttir T, Lai C, Roshan R. Perspectives on global nursing leadership: international experiences from the field. Int Nurs Rev. 2014;61(4):463 71. Available from: doi:10.1111/inr.12139 Accessed 28 June 2017.

9. Dyess SM, Sherman RO, Pratt BA, ChiangHanisko L. Growing nurse leaders: their perspectives on nursing leadership and today's practice environment. Online Issues Nurs. 2016;21(1):3. Available from: doi:10.3912 / OJIN.Vol21No01PPT04 Accessed 28 June 2017.

10. Villarruel AM, Peragallo N. Leadership development of Hispanic nurses. Nurs Admin Q. 2004;28(3):173-80. Available from: doi: 10.1097/00006216-20040700000005 Accessed 28 June 2017.

Manuscript received on 8 August 2017. Accepted for publication on 4 June 2018. 
RESUMEN

Capacitación de líderes en enfermería en toda la Región de las Américas: evaluación de un curso en línea de liderazgo en enfermería

Palabras clave
El desarrollo de las capacidades de liderazgo en el personal de enfermería es esencial para alcanzar la salud universal en la Región de las Américas. En esta evaluación se analizó la eficacia de un curso de liderazgo en línea en inglés y en español que se ofreció a personal de enfermería en toda América Latina y el Caribe. El curso en línea fue un curso asíncrono de liderazgo en enfermería de ocho módulos, creado y ofrecido por el Campus Virtual de la Organización Panamericana de la Salud (OPS). Se usó un diseño retrospectivo y descriptivo para evaluar los datos de desempeño de los alumnos en los módulos. Se analizó el desempeño de los alumnos en cuanto al aprendizaje el curso. Se enviaron encuestas electrónicas a las personas que abandonaron el curso antes de su finalización para obtener información sobre los motivos de deserción.

En total, 289 personas de 41 países participaron en los cursos en línea. Se detectaron mejoras en el desempeño de los alumnos antes y después de la prueba. La razón más frecuente por la que no completaron el curso fue que estaban muy ocupados con otras obligaciones. La versión del curso en español tuvo más inscriptos que cualquier otro curso en los 12 años del Campus Virtual. La conclusión de la evaluación fue que en toda América Latina y el Caribe se desea recibir educación continua que fomente las capacidades de liderazgo en enfermería. La educación en línea por medio del Campus Virtual de la OPS puede ser un medio económico, pero a la vez poderoso, de difundir conocimiento al personal de enfermería en la Región de las Américas.

Educación continua en enfermería; educación a distancia; capacitación de recursos humanos en salud; Américas.
RESUMO

\section{Desenvolver a liderança em enfermagem nas Américas: avaliação de um curso online de práticas de liderança em enfermagem}

Palavras-chave
Desenvolver a capacidade de liderança na equipe de enfermagem é fundamental para alcançar a saúde universal na Região das Américas. Foi realizada uma avaliação da efetividade de um curso online de práticas de liderança em enfermagem ministrado em inglês e em espanhol ao pessoal de enfermagem em toda a América Latina e o Caribe. Tratou-se de um curso online assíncrono com oito módulos sobre práticas de liderança em enfermagem, elaborado e oferecido pelo Campus Virtual da Organização Pan-Americana da Saúde (OPAS). Foi usado um delineamento descritivo retrospectivo para avaliar os dados do desempenho dos alunos nos módulos. Foram enviadas aos participantes que não concluíram o curso uma pesquisa eletrônica para a coleta de dados sobre os motivos do abandono.

Ao todo, 289 profissionais de 41 países fizeram o curso online. Houve melhoria no desempenho dos alunos entre o pré-teste e o pós-teste. Estar muito ocupado com outros compromissos foi o motivo mais frequentemente informado para não concluir o curso. O número de inscrições de profissionais no curso na versão em espanhol foi o mais alto dentre os cursos oferecidos nos 12 anos de vida do campus virtual. Esta avaliação demonstrou que existe uma demanda por educação continuada para desenvolver liderança em enfermagem na América Latina e Caribe. A educação online por meio do Campus Virtual da OPAS é um recurso de baixo custo, porém de grande influência, para difundir o conhecimento entre o pessoal de enfermagem nas Américas.

Educação continuada em enfermagem; educação a distância; capacitação de recursos humanos em saúde; Américas. 